\title{
The Political Economy of Industrial Development in Thailand
}

\author{
Shangmao Chen Fo Guang University, Taiwan
}

\begin{abstract}
Since the 1990s, governments around the world have emphasized the core concepts of globalization. Many governments initiated a series of political policies regarding liberalization and privatization in response to the inevitable phenomenon. In Southeast Asia, Thailand participated in the development as well by reconstructing its financial system to allow greater foreign capital for investments. Unfortunately, the importance of prudential regulations was underestimated, and the neglect thereafter caused the Asian Financial Crisis which initially occurred in Thailand on the second of June, 1997. The Thai government received 17.2 billion US dollars from the International Monetary Fund (IMF) to stabilize its domestic situation and implemented structural reform to minimize losses from the crisis. Meanwhile, different voices regarding the policies for globalization were expressed. These opinions mainly referred to regionalization/ regionalism and localization/ localism. This study discusses how the Thai state transformed under globalization from three industries: the Telecommunication industry, the Automobile industry, and the Cultural Creative industry. This article observes that Thailand turned to take regionalization and localization into consideration, which in turn demanded the state to increase domestic autonomy and capacity. The findings also suggest that cooperation with other governments in the region to accelerate economic recovery from the crisis was inevitable. However, political instability and close state-business relations continue to make the future of Thailand uncertain.
\end{abstract}

Keywords: Thailand, Regionalization, Localization, Industrial Development

\section{Introduction}

The Asian financial crisis in 1997 not only caused severe damages to the Thai economy, the event also caused Prime Minister Chavalit Yongchaiyudh (New
Aspiration Party) to step down from office and the succession of Chuan Leekpai (Democrat Party) as leader of the government. Once in office, Chuan carried out globalization and liberalization policies and accepted great assistance from the IMF, World Bank and 
other international organizations, in the hope of leading the Thai people out of the shadow of financial crisis with speed. However, such unconditional liberalization policy generated significant repercussions from the Thai people. It was under such condition that telecommunication tycoon Thaksin Shinawatra grasped the heart of the Thailand people and established the Thai Rak Thai Party in 1998.

In the 2001 general election, Thaksin's policy appeal to nationalist and populist sentiments enabled him to defeat the Democrat Party and become the twenty-third PM of Thailand. Not only did Thaksin implement many populist policies after entering office, under the suggestion of renowned business strategist Michael Porter and others, Thaksin selected five industries as his key policy focus: tourism, fashion, food, software and automobile (Ketels 2003; Porter 2003). The fashion, food and software industries are closely related with the cultural creative industry. The cultural creative and automobile industries thus became important windows for Thailand to respond to the globalization crisis through regionalization and localization.

Based on the examples of the telecommunication, the automobile and the cultural creative industry, this paper seeks to analyze the changing role of the Thai state under globalization. This paper argues that after Thailand's confrontation with the globalization crisis, the country turned to emphasize regionalization and localization. Through economic cooperation and integration with other countries in the region, and improvement in the state's institutional autonomy and capacity, the Thai government brought related industries onto the path of economic recovery. However, Thailand's political instability in recent years and corrupt state-business relations continue to make the future of Thailand uncertain.

The structure of this paper is as follows: section one is the introduction; section two introduces the changing role of the Thai state, including regionalization, localization and statebusiness relations; section three provides a brief introduction of Thailand's automobile, cultural creative and telecommunication industries; section four uses the automobile industry to explain Thailand's regionalization strategy; section five uses the cultural creative industry to explain how Thailand responds to globalization through localization; section six explains how Thailand exploits state-business relations to buffer its telecommunication industry and the negative impacts of political instability on related industries; section seven is the conclusion.

\section{Changing Role of the State}


After the publication of Bringing the State Back In in 1989, the state became the focus of political and economic research (Evans, Rueschemeyer \& Skocpol, 1985). At the same time, the wave of globalization began to emerge and caused great impact on the state. The zero-sum framework of thinking of academics regarding the relationship between globalization and the state began to change. The academia began to emphasize the "enabling face of globalization", which includes: (1) the increasing sense of economic insecurity, which demands the government to provide social security; (2) increased competition among states, which demands the government to provide more mechanisms for the creation of industries; (3) intensified competition among key industries, which demands the government to respond with new policies, strengthen supervision mechanisms and carry out structural reforms (Weiss 2003, pp.15-18).

In order to break away from the zerosum framework of thinking regarding globalization, when analyzing the phenomenon so called "globalization", we must emphasize the research approach of domestic institution. The challenges of globalization and economic liberalization do not deny the importance of domestic institution. Rather, Deyo(1996, p.136) argues that we must place more importance on the regulatory capacity and organization structure of domestic institution because they can increase the state capacity against globalization. It is easy to see that globalization has caused local companies to face severe competition and influenced state capacity in many ways. State capacity is therefore the variable that best explains the differences among industries of different states in a globalized age (Evans 1997).

\section{The Emergence of Regionalization}

In the Fifth WTO Ministerial Meeting of the Doha Round held in Cancun in 2003, as a result of the inability to reach consensus and ensuing deadlock regarding the issue of agriculture, many states turned to the negotiation of regional trade agreements (RTAs). Regionalism has become a very important concept of the international system today (Dent 2008, p.6). Regionalism can be divided into two categories: open regionalism and closed regionalism.

Open regionalism emphasizes the relationship between the state and the global market and regards regionalization as a complementary stage that supports state participation in the process of globalization. The regionalizing process can be considered as meso-globalization or a transitional phase before globalization. In short, regionalization should not be seen as contradictory to globalization (Munakata 2005, p.16). Open regionalism can be further divided into two branches: neoliberal regionalism and the FDI model. The FDI model 
emphasizes the importance of foreign direct investment for regionalization.

Closed regionalism focuses on the relationship between the state and society and places importance on distributional or social justice and other non-economic values. This category of regionalism considers the regionalizing process as an oppositional force against globalization. Legitimacy is an important basis for decision makers when accessing regionalism. Closed regionalism is also divided into two branches: developmental regionalism and the resistance model. Developmental regionalism places emphasis on the importance of domestic capital (Nesadurai 2003a, 2003b).

Under the influence of globalization, transnational corporations grew on a massive scale and entered into developing economies. Southeast Asia became the main target of transnational corporations. In order to counter the negative impacts of globalization, East Asian countries adopted regional cooperation (Munakata 2005, p.38). Thailand adopted the response of closed regionalism but does not shut out globalization completely. Developmental regionalism best explains the condition of Thailand.

The Response of Localization
In Thailand, the debate between globalization and localization has existed for a long time, especially after the Asian financial crisis (Hamilton-Hart 1999). After the Asian financial crisis, Chuan accepted the suggestions of IMF and carried out privatization, liberalization and other reforms. However, these reforms did not realize without negative consequences. Many of Thailand's important companies fell into foreign ownership, which generated great discontent among the Thai population.

In the birthday speech in 1997, the King pointed out the importance of the sufficiency economy based on the individual, the family and the state. He pointed out that by carrying out sufficiency, not only can the country reduce the influences of both the domestic and international market, Thailand could also decide on whether to connect with the world or not, and not be forced into the international market and free trade by globalization (Hamilton-Hart 1999, 2000; Hewison 2000). The call for sufficiency garnered great support in less developed rural areas in Thailand's northern and northeastern regions. As a result, Chuan was forced to step down from office in 2001 and hand over power to the Chiang Mai born Thaksin.

Keeping in mind the discontent IMF reform policies have generated in the past, Thaksin shifted the tone of his economic policy from market liberalization and 
globalization to an emphasis on localization (Hewison 2000), a policy later known as "Thakinomics." Thaksin's main argument was dual-track: the first track emphasizes the influence of FDI on Thailand's economic development; the second track emphasizes the importance of the domestic market. Such local based policy thinking effectively improved the capacity and autonomy of the Thai government while the economy quickly recovered. Populist localization became an effective weapon against globalization.

The example of Thailand suggests that the Thai government and the state's role were indeed affected by the negative impacts of globalization, which indirectly led to the eventual outburst of the 1997 financial crisis. Yet after the crisis, the government and the role of the state began to undergo change. The Thai government adopted a more active response towards globalization. By guiding the development of the automobile and cultural creative industries and integrating the forces of regionalization and localization, the Thai government successfully overcame the challenges of globalization.

Besides the response of regionalization and localization, Thaksin also exploited traditional state-business relations to support specific industries and facilitate Thailand's economic recovery.
State-Business Relations in the Thaksin Era

Thaksin, born on July 26, 1949 in Chiang Mai, is a fourth generation Chinese immigrant. The second and third generation ancestors of the Thaksin family engaged in the textile industry in the Chiang Mai area as early as 1932, hence it is little wonder that Thaksin inherited the business acumen of his family. After receiving his doctorate in criminal justice at Sam Houston State University in Texas in 1979, Thaksin returned to Thailand and became a police officer. Thaksin started a small computer dealership and used his father-in-law's connections in the Thai police force to expand his business effectively in the early eighties. After achieving business success through connections in the police force, Thaksin gained a deep understanding of the importance of statebusiness relations.

On July 14, 1998, Thaksin established the Thai Rak Thai Party. It was the first time in Thailand's political history that such an influential corporate figure enters into politics. Thaksin entered the 2001 general election and announced his ambition to rule the country -- Thailand officially entered the Thaksin era. Thaksin's victory in the election not only symbolized the re-emergence of business interests, the new leader's business background and his corporate relations also changed the essence of state-business relations completely, moving Thailand from money politics in the period of 
democratization to "big money politics" (Baker 2005, p.130). Thailand's new leader was able to maintain close relations with both international and domestic capital. Thaksin's rule reflects the importance of the network between the state and business. However, close statebusiness relations generated popular discontent and repulse in the end and sparked Thailand's first military coup since 1992.

\section{The Political Economy of Industries in Thailand}

\section{The Automobile Industry}

Import Substitution Period (1961-1971)

Before the 1960s, Thailand imported all its automobiles (Niyomsilpa 2008). In order to develop its own automobile industry, the Thai government passed the Industrial Promotion Act in 1960 (Doner 1987, p.415). The IPA provided incentive for investment and in the same year the IPA was introduced, several automobile assembly plants obtained licenses. In 1961, the first automobile assembly plant in Thailand, Anglo Thai Motor, was officially established. In the first year of implementation of the IPA, 310 passenger cars and 215 trucks assembled (Poapongsakorn \& Techakanont 2008, p.203; Terdudomtham 1997, p.3). However, Thailand's import substitution policy in this period was unsuccessful.
The increase in automobile import caused acute trade deficit. The Thai government was forced to change its policy and adopt a more rigid stance against foreign investment. In 1972, Thailand passed related laws to limit the influence of foreign capital on the Thai economy (Kesavatana 1989, p.107-112).

1. Protectionism Period (1971-1991)

In 1971, the Thai government established the Automobile Industry Development Committee (AIDC) under the Ministry of Industry, in the hope of facilitating the growth of the automobile industry through state assistance. Accordingly, the Thai government announced a series of policies geared towards the automobile industry. By 1975, all assembled parts should reach $25 \%$ of local content ratio, which means that at least $25 \%$ of all parts used should be made in Thailand. In 1978, the Thai government further adopted a more protectionist policy. However, protectionism increased production cost and decreased the quality of the automobile in Thailand. The high price of automobile greatly affected the sale of vehicles in Thailand and even drove away foreign corporations such as GM Holden and Chrysler/Dodge from the country (Lim \& Fong 1991, p.153-154), planting the seed for the next round of reforms.

Liberalization Period (1991-1997) 
After the military coup in February 1991, Anand Panyarachun succeeded as Thailand's eighteenth Prime Minister. The new administration decided to liberalize Thailand's automobile industry in order to lower the domestic sale price of the automobile and increase the sector's competitiveness in the world (Higashi 1995). The first step the Anand administration undertook was to lift the import ban on Complete-Built-Unit (CBU) in April 1991 and lower both the tariffs for CBU and Complete-Knock-Down (CKD) in July of the same year. In this period, Thailand's industrial policy in terms of the automobile basically corresponds to the development of globalization. The automobile industry began to be internationalized in this period. However, Thailand's policy autonomy was relatively low and measures and policies corresponding to the new development remained insufficient. In addition, the Thailand government relaxed the threshold on foreign shareholding in the same period, which caused most of the country's automobile plants to fall into foreign ownership, particularly Japanese ownership, at the end of the 1990s (Fuangkajonsak 2006). The policy change greatly affected Thailand's national interest and generated serious problems in 1997.

Post-crisis Period (1997- present)

The Asian financial crisis had a major impact on Thailand's automobile industry.
Thailand's automobile market shrunk $40 \%$ while car sales plummeted from 561,523 in 1996 to 349,033 in 1997. By 1998, the sale figure for automobiles reached only 140,402 , achieving only $1 / 4$ of the sale figure in 1996. In order to resuscitate the dying automobile industry, the Thai government undertook a series of liberalization policies. The government reinforced cooperation between the state and the private sector to promote the development of the automobile industry and improve its global competitiveness (Thailand Automobile Institute 2006). The automobile industry began to show signs of life again thanks to appropriate state policies and Thailand's activeness in entering economic cooperation in East Asia.

\section{The Cultural Creative Industry}

\section{Bangkok Fashion City (BFC)}

Under the planning off the Ministry of Industry, the BFC integrated the six biggest private corporations in Thailand and seeks to transform Bangkok into a regional hub for fashion by 2007 and an international hub for fashion by 2012, through the joint corporation of the state and private sector. BFC can be regarded as a very important cultural creative industrial policy that is quite successful in the Thaksin governmant. With the promotion of fashion in Bangkok, Thailand's design industry exceeded 300 billion baht in export while fashion textile export exceeded 130 billion baht, grossing 
$20 \%$ growth per annum. The entire plan was to be carried out from 2003 to 2007. However, with Thaksin's resignation on September 19, 2006 following a military coup, the BFC proposal came to an end, as the succeeding military government did not put forth its support.

\section{Thailand Creative and Design Center} (TCDC)

Thaksin once expressed that "creativity can create job opportunities and increase income; although creativity and economics seem like two different things, we can combine the two concepts." Under the thinking of "creative economics," the Thai government established the TCDC on September 2, 2003 and the center went into work on November 14, 2005. Beside the goal of providing professionals with the latest information in the industry, TCDC aimed to provide average citizens with creativity and design related knowledge. Accordingly, TCDC was established on the six floor of the Emporium shopping center in the heart of Bangkok (TCDC 2009). Even though the TCDC was established with government support, the fact does not diminish its effect of closing the gap between the design industry and average citizens, bringing the concept of design into the heart of the Thai people. Based on its success, the TCDC stepped out of Bangkok and established "Mini TCDCs" in other regions of the country, spreading the concept of creativity across Thailand.

\section{One Tambon, One Product (OTOP)}

The idea of OTOP came from the Japanese concept of "one village one product" (OVOP), an idea proposed by Oita Governor Hiramatsu Marihiko in 1979. Thailand's OTOP concept originated from Thaksin's plan to stimulate rural and urban economy in 2001. The Thai government allocated one million baht to 45,000 tambons across the country, in hopes of helping them develop products of local characteristic and move away from poverty. When the OTOP project began in 2001, the project grossed only 215 million baht in sales income. By 2003, OTOP sales reached 33 billion baht, with the figure rising to 46 billion baht in 2004 and 50 billion baht in 2005. Small and medium enterprises (SMEs) that participated in OTOP reached 35,179 , evidence of the project's success. Unfortunately, like the BFC, the OTOP project terminated after Thaksin's resignation, as it also failed to garner the support of the succeeding government.

\section{The Telecommunication Industry}

Thailand's rapid economic development since the 1980 s caused a corresponding growth in demand for telecommunication facilities in the country. As Thailand's two state corporations, the Telephone Organization 
of Thailand (TOT) and the Communication Authority of Thailand (CAT), could not satisfy increasing demand, the telecommunication industry began to face difficulties in the late 1980s. The Thai government was forced to consider serious reform in the telecommunication industry. In this context, the government sought the help of the private sector to provide better telecommunication service and combined such help with the country's second wave of privatization in 1984. Since the late eighties, Thailand initiated the first phase of telecommunication reforms and opened up the sector to private participation through the scheme of Build-Transfer-Operate (BTO).

\section{Telecommunication Reform Phase I (late} 1980s - 1997)

Thailand's rapid economic growth since the 1980s greatly boosted the demand for telecommunication service in the country. As a result, Chaticahi Choonhaven undertook the task of sector reform once he entered office. Under the support of TOT and CAT, the Chaticahi administration issued more than 22 telecommunication licenses, including four special concessions for fixed-line telephone and mobile phone. However, the process of issuing licenses and concessions was hampered by huge controversies (McCargo and Pathmanand 2005, p.27).
Telecommunication Reform Phase II (1997- present)

After liberalization of the telecommunication industry, the TOT and CAT played both the role of player and referee. At a time when the establishment of the National Telecommunication Commission (NTC) was under planning, privatization of the TOT and CAT became the main issue of concern in the second phase of reform. Thaksin's original plan was to have both TOT and CAT corporatize first before merging and undergoing privatization (Pathmanand and Baker 2008). According to the Telecommunications Master plan passed in 1997, privatization of TOT and CAT should be completed before October 2000. However, the privatization process was severely delayed and only the first step of TOT and CAT corporatization was completed before Thaksin was thrown out of office. The succeeding government became busy attending to political instability and did not prioritize the privatization of TOT and CAT. It is expected that TOT and CAT privatization still have a long way to go.

\section{The Response of Regionalization}

The Role of East Asian Countries

After the 1985 Plaza Accord, the Japanese yen appreciated sharply, rising from 236 yen per dollar to 125 yen per dollar. The sharp rise of the yen caused 
Japanese manufacturers to move out of the country in search of new investment grounds. Thailand became the top choice for foreign investment by Japan's automobile companies. With time, the phenomenon of Japanese growing dominance over the automobile industry in Thailand became apparent (Busser 2008). On the other hand, Thai government support for the automobile industry was another important reason for Japanese investment in the country (Takayasu and Mori 2004). In 2004, Japan became the top importer and second largest exporter of Thailand while Thailand was Japan's tenth biggest importer and sixth biggest exporter (MOEA 2006).

As the development of globalization stagnated, many countries in the AsiaPacific began to move towards regionalization and the pursuit of free trade agreements (FTAs). Thailand and Japan have long maintained a close economic relationship. The JapanThailand Economic Partnership Agreement (JTEPA) signed in 2005 clearly pointed out that Japan would support Thailand as the "Detroit of Asia" through joint cooperation in the automobile industry. Furthermore, the JETPA also mentions the plan for joint establishment of the Automotive Human Resources Development Institute (AHRDI), a concept that aims to improve the international competitiveness of the Thai automobile industry through human resource development. As the above discussion suggests, it is clear that the JETPA will improve the trade relationship between Japan and Thailand, especially the real interest of the automobile industry in both countries.

Regional Economic Integration

Tariff reduction under regional economic integration provides major benefits for the economic development of Thailand. By 2003, Thailand's average tariff rate had fallen to $4.64 \%$ (Puntasen, Lewnanonchai, \& Rattanawarinchai 2008). The development of Thailand's automobile industry is significantly related to free trade agreements with countries such as Japan, China, South Korea, Australia, New Zealand and India. At the same time, other Southeast Asian countries served as big export markets for Thai automobile. The export of automobile related products in Thailand has always remained as the country's second largest exported good. In 2009, automobile exports reached 11.1 billion USD, accounting for $7.29 \%$ of total export. In 2010, as a result of Thailand's economic recovery, automobile exports increased to 17.7 billion USD, accounting for $9.07 \%$ of total export.

On the other hand, besides the mentioning of bilateral cooperation in the automobile industry in the JETPA, tariff reduction of automobile related goods is also contained in free trade agreements 
between Thailand and Australia, India, and New Zealand. Beginning from January 2005, Australia reduced or eliminated tariffs on passenger and commercial vehicles, as well as trucks. Tariff on related vehicle parts was reduced from $42 \%$ to $20 \%$ and completely eliminated by January 2010. In short, FTA between Thailand and Australia generated a complementary, rather than a zero-sum, relationship (Chaksirinont 2005, p.40-44). In September 2006, India agreed1) to reduce tariff on Thai automobile parts as well. Finally, beginning January 2010 as well, New Zealand reduced or removed tariffs on passenger and commercial vehicles, trucks and related vehicle parts produced in Thailand (2) (Office of Industrial Economics 2006, p.19). The automobile industry can be regarded as the biggest benefactor of regional integration.

\section{The Response of Localization}

The Role of Government

Effective development of the cultural creative industry demands various government policy and institutional support, which can be discussed on three levels: policy, production, and marketing.

First, in terms of policy, Thailand's cultural creative policies are largely defined by the National Economic and 4 Social Development Board (NESDB), the Ministry of Culture (MOC), the Ministry of Science and Technology (MOST) and the Ministry of Education (MOE). Besides official ministries and departments, the Prime Minister's policy direction has important influence on the cultural creative industry as well.

Second, in terms of the production, the process can be further divided into four sections:

Finance: Financial assistance to businesses and individuals is jointly undertaken by the Ministry of Finance (MOF), the Board of Investment (BOI) and the Office of Small and Medium Enterprises Promotion (OSMEP).

Knowledge and technology: Research and development of the cultural creative industry is undertaken by the National Science and Technology Development Agency (NSTDA), the Thailand Research Fund (TRF) and the Software Industry Promotion Agency (SIPA), as well as other research institutes and universities. These agencies seek to increase the production and added valued of cultural creative products.

Quality management and standard control: The quality and standard of cultural creative production is monitored by the Food and Drug Administration (FDA), the International Organization for Standardization (ISO) and the Tourism Authority of Thailand (TAT).

Human resource: The training and development of artisans and cultural creative talent is performed by the Community Development Department 
(CDD), the Department of Intellectual Property (DIP) and universities and colleges in the country.

Finally, in terms of marketing, the Ministry of Foreign Affairs (MOFA), the Department of Export Promotion (DEP), the Department of Business Development (DBD) and the Thai Tribal Crafts Organization are responsible for the worldwide promotion of Thai cultural creative products and services.

The above description suggests that in terms of the cultural creative industry, the main role of the Thai government is to carry out policies that aim at development of the industry (Termpittayapaisith 2007).

The Importance of Economic Development

After the succession of Abhisit Vejjaji as PM in 2008, Thailand pushed forward various projects aimed at promotion of the cultural creative industry. August 31, 2009 marked the official takeoff of the "Creative Thailand" project. On September 10, Thailand established the National Creative Economy Policy Committee (NCEPC) with PM Abhisit leading the committee and advisor to the PM office, Apirak Kosayothin, serving as consultant to the committee. Building on the tide of actions towards development of the cultural creative industry, the Thai government announced that 2010 will be the "Creative Economy Year" of Thailand, an action that demonstrates the incumbent government's commitment towards the promotion of Thai culture.

At the inaugural NCEPC meeting on October 7, 2009, Abhisit expressed his aspiration for Thailand to become the hub for creative economics in Southeast Asia. In addition, he also expressed his ambition for a major increase from twelve to twenty percent in creative economy as a proportion of GDP. In order to accomplish the above goals, the Thai government integrated creative economic policies into its national economic recovery programs, the Thai Khem Khaeng and the Tenth National Economic and Social Development Plan (NESDP) (Inside Thailand 2009). Abhisit also pushed for inclusion of the concept of creative economy into the Eleventh NESDP (2012-2016), in hopes of establishing a cultural creative economy in Thailand and greatly boosting the significance of the cultural creative industry as a driving force of GDP by 2012.

The Tenth NESDP is hinged on the guiding principle of sufficiency. Under the principle, the NEDSP aims to achieve three main goals: people centered development model; a balance between economic, social and environmental capital; and the establishment of a happy and green society. In order to meet the above goals, the Thai government hopes 
to increase the influence of its knowledge based economy through the reorganization of different sectors. The agricultural, manufacturing and service sectors now all emphasize the concept of creativity.

\section{Political Instability and State-Business Relations}

The Impact of Political Instability

Thaksin's leadership style and personal business relations gave rise to strong popular discontent in the country. Thailand fell into political instability since the second half of 2005. After more than a year of political distress, on September 19, 2006, the Thai military staged the first military coup in the country since 1992 and dismissed Thaksin (Montesano 2007). Supporters of Thaksin formed the United Front of Democracy against Dictatorship (UDD) and expressed their discontent against the military government. The UDD and the People's Alliance for Democracy (PAD), led by Sondi Limthongkul, subsequently initiated massive protests against the government. It is clear that the military coup did not solve the political distress of Thailand, but rather deepened the country's political division.

Since 2005, seven candidates succeeded as Prime Minister of Thailand: Thaksin Shinawatra, Surayud Chulanont, Samak Sundaravej, Somchai Wongsawat,
Abhisit Vejjajiva, Yingluck Shinawatra, and Prayuth Chan-o-cha. Many serious conflicts broke out during this period of frequent successions. In November 2007, the so called "Yellow Shirts" occupied Suvarnabhumi and Don Muang airport and was determined to force Somchai out of office. In April 2009, the "Red Shirts" blocked the ASEAN Summit Meeting in Pattaya. On March 12, 2010, the Red Shirts launched a million people march on the streets of Bangkok and occupied the Ratchaprasong area for more than two months. The Thai security forces responded with two massive crackdowns on April 10 and May 16-19, causing the more than 90 deaths and 1,800 casualties.

In 2011, PM Abhist decided to dissolve the parliament and hold an election. The Puea Thai Party led by Thaksin's younger sister Yingluck triumphed in the election and Yingluck succeeded as the PM of Thailand. After two years in office, in 2013, Yingluck proposed an amnesty bill. The bill was opposed by former Deputy Prime Minister Suthep Thaugsuban, who would establish the People's Democratic Reform Committee (PDRC) and generate instability by initiating large scale demonstrations on the streets of Bangkok. In the end, on May 22, 2014, the Thai military once again staged a coup and took over executive and legislative powers of the state. The military expects to initiate one to two years of reform before carrying out popular elections and returning the state to the Thai people. 
Frequent overturn of the Thai regime has an impact on the sustainable development of the cultural creative industry. Although Thaksin's BFC project was not without controversies, the project contributed to the development of Thailand's cultural creative industry. Thaksin's exit from office and the military government's succession ended the project and caused developments in the fashion industry to grind to a sudden halt. Similarly, the OTOP project achieved some appealing results but was forced to change its name after the end of Thaksin's office, which generated a succession problem of Thailand's cultural creative policy.

Furthermore, political distress in 2009 also had a severe impact on Thailand's movie industry. In 2008, as many as 526 foreign film production teams worked in Thailand and generated an estimated income of 2 billion baht. However, in 2009, as a result of political chaos in Thailand, despite the slight drop in foreign teams working in Thailand to 496 , the income declined significantly to 0.8 billion baht, which severely crippled the development of the Thai movie industry (Thailand Investment Review 2010). The movie industry is a good example of the impact of politics on the cultural creative industry in Thailand.

The Impact of State-Business Relations
In an interview in 1997, Jasmine Group founder Adisai Bodharamik pointed out that in Thailand, business depends on connections (Pananond 1999). On the other hand, UCOM president Boonchai Benjarongkul also expressed that connections is always the most important factor (Niyomsilpa 2000, p.76). Thailand's main telecommunication groups also hold similar view and try hard to maintain various connections including state agencies, political figures and the military.

In the past, nearly all of the management level personnel in Thailand's state enterprises consisted of political patronage or reward. Moreover, as a result of the instability of Thai politics, the government's short terms caused constant changes on the management level in state enterprises, which further affected corporate performance significantly. In short, excessive political intervention exists in Thailand's telecommunication industry, which severely hampers sector reform (Thailand Development Research Institute 2002).

After Thaksin's entry into office, Thailand's telecommunication industry underwent change and key figures from major conglomerates joined the Thaksin administration, including the chairman of CP Group, Dhanin Chearavanont, who served as advisor to the Ministry of Finance, and Jasmine Group founder, 
Adisai Bodharamik, who served as the first Minister of Commerce (Kritsophon 2002, p.47).

On the other hand, the Thai government formed a special task force that aimed to realize the country's promise to liberalize the telecommunication industry under the WTO. The task force introduced a proposal that sought to balance competition in the telecommunication industry. The proposal was strongly opposed by an incumbent member of parliament, who is also a close friend of Thaksin, and failed to come to light. It is generally believed that opposition was to ensure the dominant advantage of Advanced Info Service (AIS) at the time.

It is clear that Thaksin exploited his connections in both the state and business communities to extract personal interests. Thaksin played an important role before and after sector reforms, whether in the license granting period, after the financial crisis or during his office. However, it is undeniable that state-business collaboration curtailed the national strategy to use the telecommunication industry for economic recovery.

\section{Conclusion}

Since suffering from the Asian financial crisis in 1997, successive governments in Thailand all deemed economic development and recovery as a state priority. At the same time, discussions of regionalization and localization appeared, and Thailand hoped to respond to globalization through the dual strategies of regionalization and localization. Although Thailand's dual strategies succeeded in helping the automobile and cultural creative industries respond to the challenges of globalization, political instability beginning in the second half of 2005 and Thaksin's personal connections damaged part of the cultural creative industry and caused reforms in the telecommunication industry to fail completely. However, the most important factors in the future are Thaksin and the current political situation. Thaksin played an important role not only in the telecommunication industry, but also all the industries in Thailand. If Thaksin return to Thailand will definitely affect the development of various industries. Meanwhile, The attitude of military government toward industrial development also determines the future of Thai political economy.

\section{About Author}

Shangmao CHEN is an associate professor at Department of Public Affairs, Fo Guang University, Taiwan. His research interests include Thai politics, Thai industrial development, and East Asian economic integration. He can be reached at smchen@mail.fgu.edu.tw 


\section{References}

Baker, C 2005, 'Pluto-Populism: Thaksin and Popular Politics', in P. Warr (ed), Thailand Beyond The Crisis, Routledge Curzon, London, pp. 107-137.

Busser, R 2008, " 'Detroit of the East'? Industrial Upgrading, Japanese Car Producers and the Development of the Automotive Industry in Thailand", Asia Pacific Business Review, vol.14, no.1, pp.29-45.

Chaksirinont, M 2005, The Effects of Thailand - Australia Free Trade Agreement: A Case Study of Automobile Industry. Master of Economics. Thammasat University, Bangkok.

Doner, RF 1987, Domestic Coalitions and Japanese Auto Firms in Southeast Asia: A Comparative Bargaining Study, Doctor of Philosophy University of California, Berkeley.

Evans, P 1997, "The Eclipse of the State? Reflections on Stateness in an Era of Globalization", World Politics, vol.50, no.1, pp. 62-87.

Evans, P., Rueschemeyer, D. \& Skocpol, T. 1985, Bringing the State Back In. Cambridge University Press, Cambridge.

Fuangkajonsak, W 2006, Industrial Policy Options for Developing Countries: The Case of the Automobile Sector in Thailand and Malaysia. Master of Arts. Tufts University.

Hamilton-Hart, N 1999, "Thailand and Globalization", Asian Perspective, vol.23, no.4, pp.287-313.
Hamilton-Hart, N 2000, 'Thailand and Globalization', in SS Kim (ed), East Asia and Globalization, Rowman \& Littlefield Publishers, Lanham, pp. 187-207.

Hewison, K 2000, "Resisting Globalization: A Study of Localism in Thailand", The Pacific Review, vol.13, no.2, pp.279-296.

Inside Thailand 2009, Developing Thailand as a Creative Economy Hub in ASEAN, retrieved from http://thailand.prd.go.th/print.php?id= 4465\&type=inside.

Kesavatana, W 1989, Political Economy of Direct Foreign Investment in Thailand: A Case Study of the Automobile Industry. Doctor of Philosophy. University of Michigan

Ketels, CHM 2003, Thailand's Competitiveness: Key Issues in Five Clusters, Institute for Strategy and Competitiveness, Harvard Business School. Boston.

Lim, LYC \& Fong, PE 1991, Foreign Direct Investment and Industrialisation in Malaysia, Singapore, Taiwan and Thailand, Development Centre of the Organisation for Economic Cooperation and Development, Paris.

McCargo, D \& Pathmanand, U 2005, The Thaksinization of Thailand, NIAS Press, Copenhagen.

MOEA 2006, Japan's Economic Cooperation Program for Thailand, MOEA, Tokyo.

Montesano, MJ 2007, 'Thailand: A Reckoning with History Begins', in D Singh \& LC Salazar (eds), Southeast Asian Affairs 2007, Institute of 
Southeast Asian Studies, Singapore, pp. 311-338.

Munakata, N 2005, Transforming East Asia: The Evolution of Regional Economic Integration, Research Institute of Economy, Trade and Industry, Tokyo. Nesadurai, HES 2003a, "Attempting Developmental Regionalism through AFTA: the Domestic Sources of Regional Governance", Third World Quarterly, vol.24, no.2, pp, 235-253.

Nesadurai, HES 2003b, Globalisation, Domestic Politics and Regionalism: The ASEAN Free Trade Area, Routledge, London.

Niyomsilpa, S 2000, The Political Economy of Telecommunications Reforms in Thailand, Pinter, London.

Niyomsilpa, S 2008, 'Industry Globalized: The Automotive Sector.' in P Phongpaichit \& C Baker (eds), Thai Capital: After the 1997 Crisis, Silkworm Books, Chiang Mai.

Office of Industrial Economics 2006, Automotive Industry in Thailand, Ministry of Industry, Bangkok.

Pananond, P 1999, "Build on Shaky Ground?: The International Expansion of Thai Telecommunication Firms", paper presented at the 7th International Conference on Thai Studies in Amsterdam.

Pathmanand, U \& Baker, C 2008, 'Hello and Goodbye to the Mobile Phone', in P Phongpaichit \& C Baker (eds), Thai Capital: After the 1997 Crisis, Silkworm Books, Chiang Mai.
Poapongsakorn, N \& Techakanont, K 2008, 'The Development of Automotive Industry Clusters and Production Networks in Thailand', in I Kuroiwa \& TM Heng (eds), Production Networks and Industrial Clusters: Integrating Economies in Southeast Asia, Institute of Southeast Asian Studies, Singapore, pp 196-258.

Porter, ME 2003, Thailand's Competitiveness: Creating the Foundations for the Higher Productivity, Institute for Strategy and Competitiveness, Harvard Business School, Boston.

Puntasen, A, Lewnanonchai, W, \& Rattanawarinchai, T 2008, 'Aspects of an Enlarged ASEAN: a Perspectives from Thailand', in TV Hoa \& C Harvie (eds), Regional Trade in Agreements in Asia, Chelteham: Edward Elgar, pp 79107.

Takayasu, K \& Mori, M 2004, 'The Global Strategies of Japanese Vehicle Assemblers and the Implications for the Thai Automobile Industry', in S Yusuf, MA Altaf \& K Nabeshima (eds), Global Production Networking and Technological Change in East Asia, World Bank, Washington D.C., pp. 209-253.

Terdudomtham, T 1997, The Automobile Industry in Thailand. Thailand Development Research Institute Foundation, Bangkok.

Thailand Automotive Institute 2006, Annual Report 2005. Thailand Automotive Institute, Bangkok. 
Thailand Development Research Institute 2002, Competition Policy under the New Constitution and the Role of the Government. Thailand Development Research Institute, Bangkok.

Thailand Investment Review 2010. May: 20(5).

Weiss, L 2003, 'Introduction: Bringing Domestic Institutions Back In', in L Weiss (ed), States in the Global Economy: Bringing Domestic Institutions Back In, Cambridge University Press, Cambridge, pp. 1-34. 